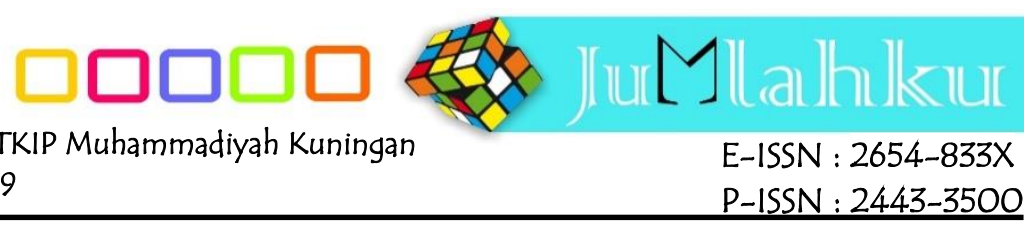

Jurnal Matematika Ilmiah STKIP Muhammadiyah Kuningan

P-ISSN : 2443-3500

\title{
Pembelajaran Matematika Materi Persamaan Garis Lurus dengan Model Guided Discovery Learning Berbantuan Geogebra
}

Muhammad Idris Septrianto ${ }^{a)}$, Jumadi ${ }^{\text {b) }}$, Uki Suhendar ${ }^{\text {b) }}$
a) MTs Muhammadiyah 1 Ponorogo
idrisseptrianto@gmail.com
b) Universitas Muhammadiyah Ponorogo jumsfkipump@gmail.com
c) Universitas Muhammadiyah Ponorogo ukisuhendar90@gmail.com

\begin{tabular}{l}
\hline \multicolumn{1}{c}{ Article Info } \\
Keywords : content; guided \\
discovery learning; \\
geogebra
\end{tabular}

Submited: $10 / 31 / 2019$

Published: 12/4/2019
This research aims to describe the results of the application of straight line equation learning with guided discovery learning model assisted by geogebra. This qualitative research took the subject is a class VIII student at MTs Muhammadiyah 1 Ponorogo. Data collection uses observation and documentation techniques. The data obtained were then analyzed descriptively. It was concluded that the application of straight line equation learning for students of class VIII of MTs Muhammadiyah 1 Ponorogo with a guided discovery learning model assisted by geogebra was carried out with the beginning of the Stimulation step, then the Problem statement, then the Data collection, followed by Data Processing, then Verification, ending with Generalization. Geogebra help is given during the stimulation and verification steps. The results of the application of this learning are student participation, confidence, and understanding increase. However, the teacher's guidance and creativity largely determine the successful implementation of the guided discovery learning model assisted by geogebra.

78

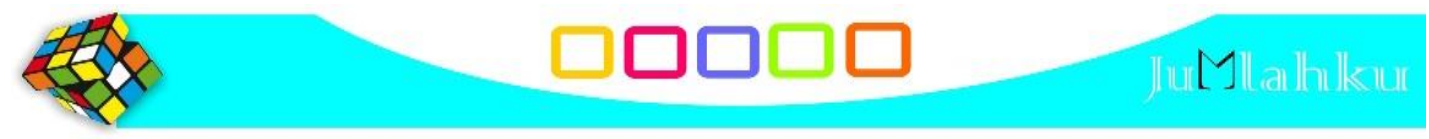


Kata Kunci: persamaan garis lurus; guided discovery learning; geogebra

\begin{abstract}
Abstrak
Penelitian ini bertujuan untuk mendeskripsikan hasil dari penerapan pembelajaran persamaan garis lurus dengan model guided discovery learning berbantuan geogebra. Penelitian kualitatif ini mengambil subjek adalah siswa kelas VIII MTs Muhammadiyah 1 Ponorogo. Pengumpulan data menggunakan teknik observasi dan dokumentasi. Data yang diperoleh kemudian dianalisis secara deskriptif. Diperoleh kesimpulan bahwa penerapan pembelajaran persamaan garis lurus bagi siswa kelas VIII MTs Muhammadiyah 1 Ponorogo dengan model guided discovery learning berbantuan geogebra dilakukan dengan diawali langkah Stimulation, lalu Problem statement, kemudian Data collection, dilanjutkan Data Processing, lantas Verification, diakhiri dengan Generalization. Bantuan geogebra diberikan saat langkah stimulation dan verification. Hasil penerapan pembelajaran ini adalah partisipasi, kepercayaan diri, dan pemahaman siswa meningkat. Namun demikian, bimbingan dan kreativitas guru sangat menentukan keberhasilan penerapan model guided discovery learning berbantuan geogebra ini.
\end{abstract}




\section{PENDAHULUAN}

Lembaga Pendidikan Tenaga Keguruan (LPTK), seperti Fakultas Keguruan dan IImu Pendidikan (FKIP) Universitas Muhammadiyah Ponorogo, diharapkan dapat meluluskan calon pendidik yang profesional. Demi mewujudkan hal tersebut maka dosen perlu membekali mahasiswa dengan permasalahan pembelajaran di kelas yang sebenarnya. Perlunya dosen di LPTK melakukan praktik pembelajaran di sekolah adalah agar mengetahui permasalahan praktis, tidak hanya secara teoritis. Karena dengan hal itu, akan dapat memberikan pengalaman yang diperoleh tersebut ke mahasiswa. Sedemikian hingga mahasiswa akan terbiasa dengan permasalahan pembelajaran yang sebenarnya, tidak hanya secara teoritis.

Bertepatan dengan kepentingan tersebut, FKIP Universitas Muhammadiyah Ponorogo merupakan salah satu LPTK yang berkesempatan menerima hibah tahun 2019 dari Ristekdikti. Hibah tersebut adalah hibah Penugasan Dosen di Sekolah (PDS). Yang mana hibah ini memfasilitasi interaksi dosen dan guru, serta dosen mengajar ke sekolah. Salah satu program studi yang diikutsertakan dalam kegiatan ini adalah program studi Pendidikan Matematika, dengan sekolah yang terpilih salah satunya adalah MTs Muhammadiyah 1 Ponorogo.

Pelaksanaan hibah PDS ini diimplementasikan dengan melakukan pembelajaran matematika untuk kelas VIII yang terdiri dari 24 siswa. Sebelum melakukan kegiatan pembelajaran, diawali kegiatan observasi oleh dosen terhadap pembelajaran yang dilakukan oleh guru. Hal ini bertujuan untuk mengetahui kultur kelas dan karakteristik siswa dalam belajar. Karena kebiasaan mengajar objek yang berbeda usia maka pasti karakteristiknya berbeda pula. Diharapkan dengan mengetahui karakteristik siswa, maka dosen dapat melakukan

perencanaan pembelajaran yang sesuai. Selain permasalahan karakteristik siswa ternyata ditemukan pula beberapa permasalahan terkait proses pembelajaran di kelas.

Masalah yang diperoleh berdasarkan observasi di kelas VIII MTs Muhammadiyah 1 Ponorogo adalah siswa yang kurang antusias dalam pembelajaran matematika. Pembelajaran yang dilakukan guru sebenarnya telah memberikan kesempatan kepada siswa untuk 
terlibat. Namun, belum digunakan siswa dengan maksimal. Seperti, ketika guru memberi kesempatan untuk mengerjakan pertanyaan di depan kelas, tidak ada siswa yang merespon kalau tidak ditunjuk. Walaupun setelah ditunjuk ternyata mereka bisa mengerjakan dengan benar. Bahkan beberapa siswa tertidur saat pembelajaran berlangsung, walaupun sudah ditegur berkali-kali. Ketika guru memberikan kesempatan menulis di catatan masing-masing, banyak siswa tidak menggunakan kesempatan tersebut dengan baik. Ditemukan sebagian siswa yang menggambar kartun maupun hal lain yang tidak terkait materi.

Beberapa masalah tersebut mungkin juga dikarenakan materi yang sedang dipelajari cukup abstrak, yakni persamaan garis lurus. Apalagi guru menjelaskan materi tidak disertai media yang sesuai. Pengenalan konsep garis lurus cukup sulit diterima oleh siswa. Saat dilakukan wawancara singkat dengan salah satu siswa yang tidak memperhatikan, diperoleh alasannya adalah karena tidak memahami materi yang dijelaskan. Kurang terlibatnya dalam proses pembelajaran juga dikarenakan mereka tidak percaya diri dengan kemampuan yang dimiliki.
Berawal dari hasil observasi dan wawancara tersebut, lantas dirancang rencana pembelajaran yang sesuai. Untuk dapat melaksanakan pembelajaran di kelas tentu membutuhkan model pembelajaran yang sesuai. Walaupun sebelumnya guru telah melaksanakan pembelajaran yang memberi kesempatan siswa aktif, namun ternyata siswa masih belum antusias. Dikarenakan karakteristik siswa yang kurang partisipatif dalam pembelajaran, maka dipilihlah model guided discovery learning. Model ini dianggap cocok dengan karakteristik siswa kelas VIII MTs Muhammadiyah 1 Ponorogo.

Dalam model pembelajaran guided discovery learning, siswa diberikan kegiatan yang membutuhkan proses mental dengan tujuan menemukan suatu konsep atau prinsip, kegiatan ini telah disiapkan oleh guru sebelumnya (Ulumi dkk., 2015). Dengan kegiatan menemukan sendiri inilah diharapkan siswa akan lebih partisipatif. Lebih lanjut Eggen dan Kauchak (2012) menjelaskan bahwa dalam penemuan terbimbing, maka guru menyajikan contoh dari topik secara spesifik dan siswa dipandu untuk memahami topik tersebut. Diharapkan dengan 
karakteristik model guided discovery learning ini akan membuat siswa lebih partisipatif karena adanya bimbingan dari guru.

Langkah-langkah dalam pembelajaran menggunakan guided discovery learning menurut Eggen dan Kauchak (2012) meliputi (a) Fase pendahuluan, (b) Fase pertanyaan terbuka, (c) Fase konvergen, (d) Penutup dan penerapan. Sedangkan menurut Syah (2004), guided discovery learning memiliki langkah (a) Stimulation (stimulasi/pemberian rangsangan), (b) Problem statement (pernyataan/ identifikasi masalah), (c) Data collection (pengumpulan data), (d) Data Processing (pengolahan data), (e) Verification (pembuktian), dan (f) Generalization (menarik kesimpulan/generalisasi). Dalam penelitian ini menggunakan langkah menurut Syah (2004).

Beberapa penelitian terdahulu menunjukkan keberhasilan penggunaan guided discovery learning dalam pembelajaran. Seperti penelitian yang dilakukan oleh Lestari (2017), yang menghasilkan bahwa model guided discovery learning efektif digunakan sebagai model pembelajaran pada pokok bahasan geometri. Hasil ini tentu mendukung penelitian yang akan dilakukan, karena materi yang digunakan juga masuk ranah geometri. Penelitian lainnya menyimpulkan bahwa respon siswa terhadap model pembelajaran guided discovery learning sangat positif (Maya dkk., 2018). Diharapkan pula penerapan model ini dalam pembelajaran di kelas VIII MTs Muhammadiyah 1 Ponorogo juga akan direspon secara positif.

Menurut Lavine terdapat empat tahapan utama dalam guided discovery learning yaitu (1) adanya kerangka kerja pembelajaran bagi siswa, (2) adanya tanggung jawab siswa dalam pencarian materi yang diperlukan untuk dipahami (3) terdapat pembimbingan dalam pembelajaran (4) aplikasi dalam menemukan dan memecahkan masalah (Sucipta dkk., 2018). Tahapan pertama menunjukkan rencana kerja siswa yang harus disiapkan guru sebelumnya. Tahapan kedua menuntut partisipasi dari siswa dalam pembelajaran. Peran guru dalam membimbing siswa ada di tahap ketiga. Tahap keempat mengharapkan ada media yang dapat digunakan dalam proses menyelesaikan kerja siswa.

Untuk memenuhi tahap yang keempat, maka peneliti memilih geogebra sebagai media yang 
digunakan dalam melaksanakan penelitian ini. Hal ini juga dengan pertimbangan materi yang sedang dipelajari relevan dengan geogebra, yakni persamaan garis lurus. Menurut Hohenwarter (2008), GeoGebra merupakan program komputer yang membantu dalam pembelajaran matematika khsususnya materi geometri dan aljabar. Supriadi (2015) mengungkapkan bahwa visualisasi menarik yang diberikan geogebra, seperti digerakkan maupun diubah bentuk serta ukurannya, dapat mengakomodasi kegiatan eksplorasi maupun observasi yang dilakukan siswa dengan lebih mudah. Media yang tepat untuk mengajarkan persamaan garis lurus adalah menggunakan geogebra.

Selain itu hasil penelitian Purwanti dkk. (2016) menyatakan bahwa terdapat pengaruh pembelajaran discovery learning berbantuan geogebra terhadap pemahaman konsep matematis. Hasil ini menguatkan harapan peneliti untuk dapat mengaktifkan partisipasi siswa yang lemah karena tidak paham materi. Lebih lanjut diperkuat hasil penelitian Akhirni dan Mahmudi (2015) yang menyimpulkan bahwa pemanfaatan geogebra berpengaruh baik ditinjau dari hasil belajar dan motivasi siswa SMP N 5 Sleman.

Dengan bantuan geogebra diharapkan dapat menambah pula motivasi yang dimiliki siswa. Penelitian Nurfadilah dan Suhendar (2018) juga menghasilkan bahwa penggunaan media geogebra di kelas eksperimen berpengaruh positif terhadap kemampuan pemecahan masalah siswa dibandingkan dengan pembelajaran konvensional.

Berdasarkan informasi dari guru, sebelumnya tidak pernah dilaksanakan pembelajaran guided discovery learning dengan bantuan geogebra di MTs Muhammadiyah 1 Ponorogo. Adanya berbagai permasalahan yang dialami siswa, khususnya dalam hal partisipasi, membuat peneliti merasa perlu melakukan penelitian. Penelitian ini bertujuan untuk mengetahui hasil dari penerapan model guided discovery learning berbantuan geogebra di kelas VIII MTs Muhammadiyah 1 Ponorogo dalam pembelajaran persamaan garis lurus.

\section{METODE}

Penelitian ini merupakan penelitian kualitatif. Dengan tujuan mendeskripsikan hasil dari penerapan pembelajaran persamaan garis lurus dengan model guided discovery 
learning berbantuan geogebra. Subjek penelitian yang ditentukan adalah siswa kelas VIII MTs Muhammadiyah 1 Ponorogo yang berjumlah 24 anak. Pembelajaran dilakukan oleh tim peneliti yang terdiri dari tiga orang, 1 orang guru matematika dan 2 orang dosen program studi Pendidikan Matematika UNMUH Ponorogo. Penelitian dilaksanakan di MTS Muhammadiyah 1 Ponorogo yang beralamat di JI Stadion Timur No 20 B. Waktu penelitian mulai tanggal 9 September-10 Oktober 2019.

Pengumpulan data menggunakan teknik observasi dan dokumentasi. Teknik observasi digunakan untuk mengetahui sikap siswa serta proses pelaksanaan pembelajaran materi persamaan garis lurus di kelas VIII. Sedangkan untuk teknik dokumentasi digunakan untuk mendapatkan data yang mendukung hasil penelitian. Instrumen yang digunakan meliputi lembar observasi, dokumen pembelajaran, dan kamera. Data yang diperoleh kemudian dianalisis secara deskriptif untuk mendapatkan kesimpulan tentang hasil penerapan pembelajaran dengan model guided discovery learning berbantuan geogebra. Kehadiran peneliti dilakukan secara terus-menerus selama pelaksanaan penelitian berlangsung demi menjaga keabsahan data hasil penelitian yang diperoleh.

\section{HASIL DAN PEMBAHASAN}

Penelitian ini dilaksanakan dalam 8 kali pertemuan. Pertemuan pertama adalah observasi kegiatan guru, yang mana akhirnya ditemukan beberapa permasalahan. Salahsatunya adalah rendahnya partisipasi siswa, khususnya dalam pembelajaran persamaan garis lurus. Bermula dari beberapa permasalahan di kelas VIII MTs Muhammadiyah 1 Ponorogo, maka dilakukanlah pembelajaran dengan menggunakan model guided discovery learning berbantuan geogebra. Yang mana penerapannya dilakukan sebanyak 6 kali pertemuan di sekolah, dan 1 kali di laboratorium komputasi

Universitas Muhammadiyah Ponorogo.

Pembelajaran persamaan garis lurus dengan menerapkan guided discovery learning berbantuan geogebra dalam penelitian ini merujuk pada Syah (2004). Dengan uraian tiap langkah sebagai berikut.

(a) Stimulation (pemberian rangsangan), langkah ini peneliti terapkan dengan mengorientasikan siswa ke tujuan pembelajaran. Misalnya dengan 
memberikan motivasi kegunaan materi yang akan dipelajari. Pernah juga peneliti menarik rasa ingin tahu siswa dengan meminta beberapa siswa melakukan simulasi cara menggambar garis lurus melalui dua titik dengan geogebra, seperti pada gambar 1 . Di awal pertemuan kedua dan ketiga, beberapa siswa masih perlu untuk dibimbing agar lebih memperhatikan stimulus yang diberikan. Jika diminta ke depan kelas untuk praktik masih malumalu dan perlu dimotivasi dahulu. Namun setelah pertemuan ketiga sebagian besar siswa dapat mengikuti dengan baik langkah ini.

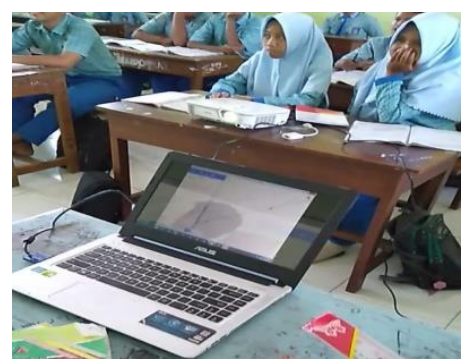

Gambar 1. Pemberian stimulus menggunakan geogebra

(b) Problem statement (pernyataan/identifikasi masalah), dalam langkah ini peneliti menyiapkan lembar kerja siswa yang diawali dengan permasalahan terkait konsep yang akan dipelajari. Ketika mengetahui ada lembar kerja yang berbeda dari biasanya mereka gunakan, siswa antusias membaca dan memahami masalah yang diberikan.

(c) Data collection (pengumpulan data), langkah ini berkaitan dengan langkah sebelumnya. Langkah ini tertuang di lembar kerja, misalnya ketika ingin menemukan gradien garis lurus, maka siswa diminta menentukan dua titik sebarang yang dilalui garis tersebut. Hasil yang diperoleh juga berbeda-beda tiap siswa atau kelompok. Pembelajaran kadang divariasi dengan pembelajaran kelompok agar siswa terlatih melakukan kerjasama, seperti terlihat pada gambar 2. Bimbingan guru dalam langkah ini sebagian besar tertuang dalam lembar kerja, banyak pertanyaan-pertanyaan yang memang ditujukan untuk mengumpulkan data yang dapat digunakan pada langkah selanjutnya. 


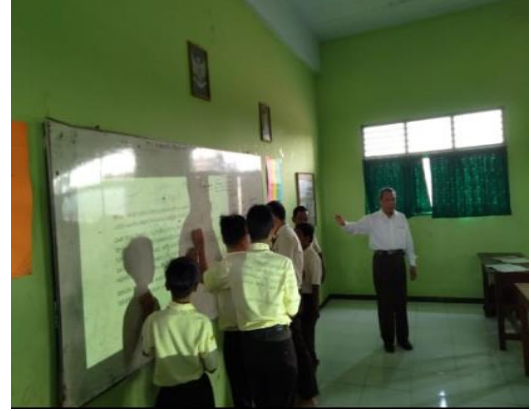

Gambar 2. Siswa secara berkelompok mengumpulkan data

(d) Data Processing (pengolahan data), siswa melakukan pengolahan data yang telah diperoleh sebelumnya. Karena dalam mempelajari konsep persamaan garis lurus banyak variasi data yang bisa dikumpulkan, maka hasilnya pun variatif. Hal inilah yang akhirnya membuat siswa mau mengikuti proses pembelajaran, karena tidak dapat mengandalkan hasil kerja temannya. Mereka harus mengolah sendiri data yang mereka peroleh agar dapat menemukan jawaban. Keaktifan siswa pun sangat meningkat dibanding pertemuan sebelumnya. Meskipun demikian, guru tetap membimbing siswa ketika mengalami kendala, sehingga waktu pembelajaran dapat mencukupi hingga tercapai tujuan yang diinginkan.

(e) Verification (pembuktian), langkah ini peneliti siasati dengan menggunakan bantuan geogebra untuk meyakinkan siswa bahwa apa yang mereka peroleh telah benar atau belum. Misalnya, ketika siswa diminta menemukan persamaan suatu garis lurus jika diketahui dua titik, maka temuan mereka diverifikasi dengan bantuan geogebra, seperti ditunjukkan dalam gambar 3 . Kesempatan lain juga dengan meminta siswa menyampaikan hasil yang diperoleh di depan kelas untuk ditanggapi teman yang lain. Antusiasme siswa juga terlihat pada langkah ini, 4 pertemuan terakhir bahkan siswa sudah berani maju tanpa harus ditunjuk dahulu.

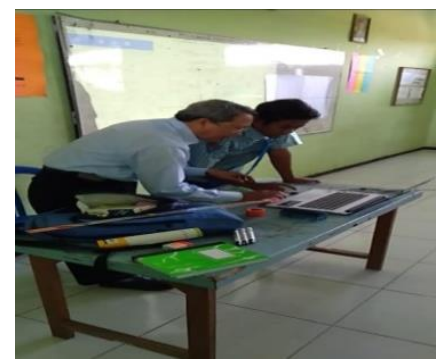

Gambar 3. Salah satu siswa melakukan verifikasi di depan kelas 
(f) Generalization (menarik kesimpulan), langkah ini peneliti lakukan dengan membimbing siswa menyimpulkan dari hasil yang mereka peroleh di langkah sebelumnya. Selama pertemuan, hampir langkah ini dilakukan secara klasikal, seperti pada gambar 4. Siswa kembali terlihat aktif dengan menuliskan kesimpulan di buku catatan mereka. Beberapa siswa sempat ditanya oleh tim peneliti yang bertugas sebagai observer. Ketika ditanya mengapa mereka mau menulis, jawaban mereka adalah karena telah paham dengan kesimpulan yang diperoleh, sehingga mereka dapat menulis yang mereka pahami.

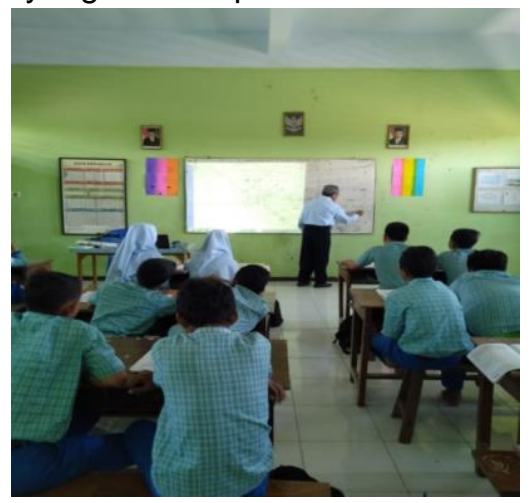

Gambar 4. Guru bersama siswa menarik kesimpulan bersama
Berdasarkan penerapan dari setiap langkah model guided discovery learning berbantuan geogebra tersebut, maka dapat dikatakan penerapan tersebut telah sesuai dengan karakteristik penemuan terbimbing yang disampaikan oleh Eggen dan Kauchak (2012). Yakni pembelajaran dengan penyajian contoh yang terinci dan dibimbing oleh guru dalam pengerjaannya. Pada langkah mengumpulkan data dan mengolah data, siswa diharuskan melalui proses mental untuk menyelesaikan. Hal ini sesuai dengan pendapat Ulumi dkk. (2015).

Partisipasi, keaktifan dan pemahaman siswa yang meningkat juga sejalan dengan hasil penelitian Maya dkk. (2018) dan Lestari (2017). Langkah pada lembar kerja berbasis model guided discovery learning yang digunakan sangat membantu siswa dalam memahami materi. Bagaimana alur pengerjaan yang runtut dan bimbingan dari guru mendukung siswa untuk turut serta dalam proses pembelajaran. Saat observasi terdapat siswa yang tidur di kelas, namun setelah diterapkan model ini siswa nampak tidak kehilangan fokusnya selama pembelajaran. Karena masing-masing mampu berkontribusi dalam menyelesaikan 
masalah yang diberikan. Meskipun harus banyak diberi motivasi dahulu.

Penggunaan aplikasi atau media dalam langkah pemecahan masalah memang dibutuhkan dalam penerapan model guided discovery learning, seperti pendapat Sucipta dkk. (2018). Media ini dapat diberikan di awal pembelajaran sebagai stimulus bagi siswa. Penggunaan media di tengah-tengah pembelajaran juga sangat memungkinkan. Namun, dalam penelitian ini media lebih sering digunakan di akhir pembelajaran, yakni pada langkah verifikasi. Yakni saat mencocokkan hasil temuan siswa dengan hasil olah data di geogebra. Sehingga secara langsung siswa dapat melakukan verifikasi.

Kegiatan verifikasi hasil temuan siswa dengan bantuan geogebra tersebut sangat mudah dilakukan. Karena geogebra menyediakan fiturfitur yang sesuai dengan materi persamaan garis lurus. Seperti membuat titik, membuat garis lurus, hingga menentukan persamaan dari suatu garis sebarang. Hal ini sesuai dengan pendapat Supriadi (2015) yang menyatakan bahwa geogebra memiliki visualisasi yang cukup menarik untuk kegiatan eksplorasi.

Hasil penelitian ini juga selaras dengan hasil penelitian Purwanti dkk.
(2016). Yang mana menyatakan bahwa terdapat pengaruh pembelajaran discovery learning berbantuan geogebra terhadap pemahaman konsep matematis. Seperti jawaban siswa ketika ditanya mengapa mau menuliskan kesimpulan di catatan, jawabannya adalah karena mereka telah paham. Konsisten dengan jawaban mereka saat wawancara singkat di pertemuan pertama, tidak menulis karena tidak paham apa yang mau ditulis.

Partisipasi dan kepercayaan diri untuk menyampaikan hasil pekerjaan di depan kelas menunjukkan bahwa siswa termotivasi untuk belajar. Seperti hasil penelitian Akhirni dan Mahmudi (2015) yang menyimpulkan bahwa pemanfaatan geogebra berpengaruh baik ditinjau dari hasil belajar dan motivasi siswa. Dalam penelitian ini, ketika siswa diminta mencoba menggunakan geogebra untuk menggambar sebarang garis lurus, mereka berlomba untuk mencoba. Namun demikian, awalnya mereka masih takut dan malu untuk mencoba, namun setelah dimotivasi dan melihat temannya bisa, mereka antusias untuk juga ikut mencoba.

\section{PENUTUP}

Simpulan 
Kesimpulan penelitian ini adalah penerapan pembelajaran persamaan garis lurus bagi siswa kelas VIII MTs Muhammadiyah 1 Ponorogo dengan model guided discovery learning berbantuan geogebra dilakukan dengan diawali langkah Stimulation, lalu Problem statement, kemudian Data collection, dilanjutkan Data Processing, lantas Verification, diakhiri dengan Generalization. Bantuan geogebra diberikan saat langkah stimulation dan verification. Hasil penerapan pembelajaran ini adalah partisipasi dan kepercayaan diri siswa meningkat, pemahaman siswa juga menjadi lebih baik. Namun demikian, bimbingan dan kreativitas guru sangat menentukan keberhasilan penerapan model guided discovery learning berbantuan geogebra ini.

\section{Saran}

Saran bagi peneliti selanjutnya adalah dapat meneliti keberhasilan penerapan model pembelajaran guided discovery learning berbantuan geogebra dengan instrumen yang lain, karena dalam penelitian ini sebatas menggunakan lembar observasi dan dokumentasi saja.

\section{DAFTAR PUSTAKA}

Akhirni, A., \& Mahmudi, A. 2015. Pengaruh pemanfaatan cabri $3 d$ dan geogebra pada pembelajaran geometri ditinjau dari hasil belajar dan motivasi. Jurnal Pendidikan Matematika dan Sains. 3(2): 91100.

Eggen \& Kauchak. 2012. Strategi Dan Model Pembelajaran, Edisi ke-6. Jakarta: Indeks.

Hohenwarter, M. 2008. Teaching and learning calculus with free dynamic mathematics software geogebra. Diunduh https://pdfs.semanticscholar.org/1 c8c/9f4765c2ad5080b59b08e3b7 7b036e780a5f.pdf tanggal 29 Oktober 2019.

Lestari, W. 2017. Efektivitas model pembelajaran guided discovery learning terhadap hasil belajar matematika. Jurnal SAP. 2(1): 6474.

Maya, Y., Ibrahim, L., \& Safrina, K. 2018. Penerapan model pembelajaran guided discovery learning (gdl) untuk meningkatkan hasil belajar pada siswa SMPN 1 Bandar Baru. Al-Khawarizmi: Jurnal Pendidikan dan Pembelajaran Matematika. 2(2): 115-122.

Nurfadilah, U., \& Suhendar, U. 2018. Pengaruh penggunaan geogebra terhadap kemampuan pemecahan masalah siswa pada topik garis 
dan sudut. Jurnal Matematika dan Pendidikan Matematika. 3(2): 99107.

Purwanti, R.D., Pratiwi, D.D., \& Rinaldi, A. 2016. Pengaruh pembelajaran berbatuan geogebra terhadap pemahaman konsep matematis ditinjau dari gaya kognitif. Al-Jabar: Jurnal Pendidikan Matematika. 7(1): 115122.

Sucipta, Ahman, E., \& Budiwati, N. 2018. Metode guided discovery learning terhadap tingkat berpikir kritis siswa dilihat dari motivasi belajar. Indonesian Journal of Economics Education. 1(1): 1-8.

Supriadi, N. 2015. Pembelajaran Geometri Berbasis Geogebra Sebagai Upaya Meningkatkan Kemampuan Komunikasi Matematis. Al-Jabar: Jurnal Pendidikan Matematika. 6(2): 99109.

Syah, M. 2004. Psikologi Pendidikan Suatu Pendekatan Baru. Bandung: PT Remaja Rosdakarya.

Ulumi, D.F., Maridi, \& Rinanto, Y. 2015. Pengaruh model pembelajaran guided discovery learning terhadap hasil belajar biologi di SMA Negeri 2 Sukoharjo tahun pelajaran 2013/2014. Jurnal Pendidikan Biologi. 7(2): 68-79. 